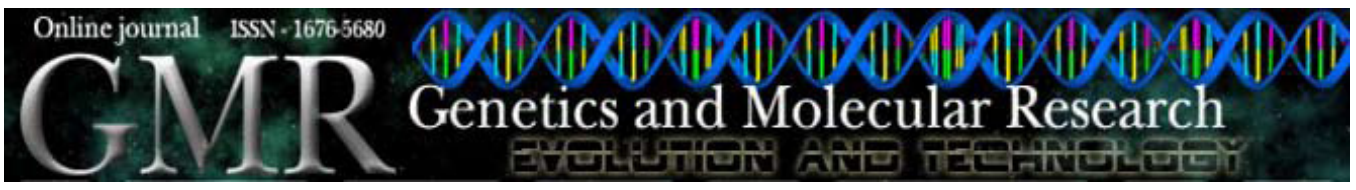

\title{
Optimizing the efficiency of the touchdown technique for detecting inter-simple sequence repeat markers in corn (Zea mays)
}

\author{
E.C. Oliveira, A.T. Amaral Júnior, L.S.A. Gonçalves, G.F. Pena, \\ S.P. Freitas Júnior, R.M. Ribeiro and M.G. Pereira \\ Universidade Estadual do Norte Fluminense Darcy Ribeiro, \\ Campos dos Goytacazes, RJ, Brasil \\ Corresponding author: A.T. Amaral Júnior \\ E-mail: amaraljr@pq.cnpq.br
}

Genet. Mol. Res. 9 (2): 835-842 (2010)

Received January 13, 2010

Accepted February 9, 2010

Published May 4, 2010

DOI 10.4238/vol9-2gmr767

\begin{abstract}
We evaluated the efficiency of the touchdown method to determine the ideal PCR conditions for distinct inter-simple sequence repeat primers for processing DNA from common corn, popcorn, sweet corn, and a Tripsacum-maize hybrid. Genomic DNA was extracted from eight accessions of corn: two of the dent type, one Tripsacummaize hybrid, one sweet corn, one flint-type corn, and three popcorn. Fifteen inter-simple sequence repeat primers were used: $(\mathrm{CT})_{8} \mathrm{RC}$, $(\mathrm{CT})_{8} \mathrm{TG},(\mathrm{GA})_{8} \mathrm{~T},(\mathrm{GA})_{8} \mathrm{YC},(\mathrm{CTC})_{5} \mathrm{RC},(\mathrm{GTC})_{6},(\mathrm{GA})_{6} \mathrm{CC},(\mathrm{GT})_{6} \mathrm{CC}$, $(\mathrm{CAC})_{3} \mathrm{GC},(\mathrm{AG})_{8} \mathrm{YT},(\mathrm{AC})_{8} \mathrm{CT},(\mathrm{AC})_{8} \mathrm{YG},(\mathrm{CT})_{8} \mathrm{RG},(\mathrm{GGAT})_{3} \mathrm{GA}$, and $(\mathrm{GAA})_{6} \mathrm{AA}$. The annealing temperature and the melting temperature for each primer were estimated using a formula for RW Genes products, or we used the temperatures indicated by the manufacturer (Invitrogen). The touchdown method was then applied to each primer, varying the number of final cycles (10 or 12) and the decrease in temperature $\left(0.5^{\circ}\right.$ or $1.0^{\circ} \mathrm{C}$ intervals). The gels were compared, considering the revelation quality, band sharpness and the number of bands visualized. The touchdown-PCR method was more efficient for band amplification for most of the primers, especially at higher annealing temperatures.
\end{abstract}


This type of system is useful for reducing the resources, time and effort needed for optimizing temperature conditions for a group of representative primers.

Key words: PCR; Method evaluation; Molecular marker; Laboratory optimization; ISSR

\section{INTRODUCTION}

Molecular markers are considered to be powerful tools in plant breeding programs due to the great variety of applications, such as assisted selection, genetic variation in quantitative traits, co-segregation analysis, and mapping of the quantitative traits, among others (Eathington et al., 2007; Schulman, 2007; Bernardo, 2008; Gonçalves et al., 2009).

The first molecular markers to be established were the isoenzymes (Market and Moller, 1959). However, these markers are fairly criticized for having a reduced coverage in the genomes investigated, due to the small number of loci that can be detected, besides the low level of polymorphism identified per locus. The discovery and isolation of restriction enzymes (endonucleases) in 1960 made possible the emergence of a new class of molecular markers called restriction fragment length polymorphisms and minisatellites, which allow the detection of differences between individuals using genomic DNA. In spite of the fact that these markers have shown various advantages, they are laborious and expensive, and besides, they are slow in producing results because they involve the execution of various stages (Schlötterer, 2004; Schulman, 2007).

In 1987, Mulis and Faloona published the classic article "Specific synthesis of DNA in vitro via a polymerase catalysed chain reaction", which consisted of the development of the technique of amplifying DNA fragments in vitro on an exponential scale. This technique, later called polymerase chain reaction (PCR) revolutionized research in molecular biology, allowing the development of different sequence markers, namely single sequence repeats, random amplified polymorphic DNA, sequence tagged sites, expressed sequence tags, sequence characterized amplified regions, inter-simple sequence repeats (ISSR), amplified fragment length polymorphism, and single nucleotide polymorphisms, among others (Schlötterer, 2004; Schulman, 2007).

The PCR technique needs two primers that flank the sequence of target DNA in order to work, plus dNTPs (the four deoxynucleotides), Taq polymerase, magnesium ions, and reaction buffer (Roux, 1995; Kubista et al., 2006). The reaction is carried out in successive temperature cycles in three stages: 1 ) denaturation at high temperature (about $92-95^{\circ} \mathrm{C}$ ) to separate the DNA strands; 2) annealing of the primers, lowering the temperature between $35-60^{\circ} \mathrm{C}$, and 3) extension, in which the temperature is set at around $72^{\circ} \mathrm{C}$, which is great for the polymerase activity to amplify the DNA fragment of interest from the 3'-OH end free of primers, incorporating the dNTPs (Kubista et al., 2006).

However, for a good functioning and reliability of the markers used in PCR, a previous standardization of the reaction conditions is necessary, so that nonspecific and unwanted amplifications are avoided (Hyndman and Mitsuhashi, 2003). Subsequently, different components and stages have to be standardized to obtain satisfactory results in the reactions, for instance, the optimal concentration of $\mathrm{Mg}^{2+}$, the design of the primers, and the conditions of the cycles, where annealing temperature $\left(\mathrm{T}_{\mathrm{a}}\right)$ is considered one of the more important components. In this respect, if $\mathrm{T}_{\mathrm{a}}$ is too high, the primers anneal in a deficient way, resulting in low 
production of amplified DNA; however, if $\mathrm{T}_{\mathrm{a}}$ is too low, nonspecific annealing of the primers can occur, which causes the amplification of undesired DNA segments (Roux, 1995; Hyndman and Mitsuhashi, 2003).

In general, to solve this problem, $\mathrm{T}_{\mathrm{a}}$ can be obtained using a temperature gradient, on average, $2-10^{\circ} \mathrm{C}$ below the annealing temperature $\left(\mathrm{T}_{\mathrm{m}}\right.$ - melting temperature), which is defined according to some factors such as the presence of GC in the fragment of the DNA target. Another option is to incorporate the touchdown method, in which the thermocycler is programmed up to a certain cycle and the $\mathrm{T}_{\mathrm{a}}$ should be decreased gradually at each cycle (Don, 1991; Roux, 1995; Hyndman and Mitsuhashi, 2003; Caixeta et al., 2006).

Some studies that have used ISSR markers also used a constant annealing temperature unique or not for all primers (Kantety et al., 1995; Carvalho et al., 2002; Fernandez et al., 2002; Debnath, 2007); others have used constant temperature for some primers and the touchdown method for the rest of the group of primers (Martins et al., 2003, 2004).

In the cases in which the touchdown method was used, there was no information about the tests to say in which cycle and how many degrees the annealing temperature must be reduced, which affects the efficiency of the touchdown method. With the occurrence of new studies using ISSR in Zea mays, such situation becomes even more complex, and therefore, a larger number of bands of dubious specificity may be considered.

Therefore, the present study was believed to be warranted. The aim was to assess the efficiency of the touchdown method, varying the number of cycles and the reduction in temperature and also to determine the ideal PCR conditions for different ISSR primers in the cultivation of common corn, popcorn, sweet corn, and tripsacoids.

\section{MATERIAL AND METHODS}

\section{Genetic material and genomic DNA extraction}

The genotypes were selected to represent a range of germplasm used in corn research at UENF. Eight accessions of corn were used, namely "Centralmex" (common corn of the dent type), "Tripsacum-maize hybrid", "Doce de Cuba" (sweet corn), "Cimmyt" (common corn of the flint type), "Cateto Amarelo" (common corn of the dent type), "IAC-112" (popcorn), "BOZM 260" (popcorn), and "PR 023" (popcorn).

Total genomic DNA was extracted from young leaves of the accessions, using the methodology described by Doyle and Doyle (1990), with some modifications according to Daher et al. (2002). After DNA extraction, DNA was quantified by $1 \%$ agarose gel electrophoresis. The marker used was High DNA Mass Ladder (Invitrogen, USA). The gel was stained with a mixture of Blue Juice $6 \mathrm{X}(0.4 \mathrm{~mL} 0.5 \mathrm{M}$ TAE; $0.2 \mathrm{~mL} 10 \% \mathrm{SDS} ; 0.2 \mathrm{~mL}$ bromophenol blue; $7.0 \mathrm{~mL}$ glycerol; $1.7 \mathrm{~mL}$ sterile water) with Gel Red 5X (1 $\mu \mathrm{L}$ Gel Red 10,000X in 0.5 $\mathrm{mL}$ dimethyl sulfoxide (DMSO); $2 \mathrm{~mL}$ ultrapure water), in a proportion of $1: 1$, and the image was revealed by the MiniBis Pro system.

\section{Inter-simple sequence repeat}

A total of 15 primers were used, including 10 dinucleotides, 4 trinucleotides and 1 tetranucleotide. Of these primers, 6 were synthesized by RW Genes: $(\mathrm{CT})_{8} \mathrm{RC},(\mathrm{CT})_{8} \mathrm{TG},(\mathrm{GA})_{8} \mathrm{~T}$, 
$(\mathrm{GA})_{8} \mathrm{YC},(\mathrm{CTC})_{5} \mathrm{RC}$, and $(\mathrm{GTC})_{6}$, and 9 by Invitrogen: $(\mathrm{GA})_{6} \mathrm{CC},(\mathrm{GT})_{6} \mathrm{CC},(\mathrm{CAC})_{3} \mathrm{GC}$, $(\mathrm{AG})_{8} \mathrm{YT},(\mathrm{AC})_{8} \mathrm{CT},(\mathrm{AC})_{8} \mathrm{YG},(\mathrm{CT})_{8} \mathrm{RG},(\mathrm{GGAT})_{3} \mathrm{GA}$, and $(\mathrm{GAA})_{6} \mathrm{AA}$.

The PCR amplification reactions were according to Zietkiewicz et al. (1994) with modifications, and carried out in a final volume of $20 \mu \mathrm{L}$ containing the following: $2 \mu \mathrm{L} 10 \mathrm{X}$ buffer (500 mM KCl, $100 \mathrm{mM}$ Tris-HCl, pH 8.4, 1\% Triton X-100), $2 \mu \mathrm{L} 25 \mathrm{mM} \mathrm{MgCl}, 1.6$ $\mu \mathrm{L} 2 \mathrm{mM}$ dNTPs, $1 \mu \mathrm{L}$ DMSO, $1.8 \mu \mathrm{L} 0.5 \mathrm{mM}$ primer (RW Genes and Invitrogen), $0.12 \mu \mathrm{L}$ $5 \mathrm{U}$ Taq DNA polymerase (Fermentas) and $2 \mu \mathrm{L} 5 \mathrm{ng}$ genomic DNA, completing the final volume with ultra pure water.

The amplifications for determining the optimal $\mathrm{T}_{\mathrm{a}}$ were done in an Eppendorf gradient thermocycler, according to the following program: 4 min of denaturation at $94^{\circ} \mathrm{C}$, followed by 42 cycles of amplification $\left(94^{\circ} \mathrm{C}\right.$ for $1 \mathrm{~min}, 1 \mathrm{~min}$ with $\mathrm{T}_{\mathrm{m}}$ (melting temperature) - varying over a range of $2^{\circ}$ to $14^{\circ} \mathrm{C}$ at $2^{\circ} \mathrm{C}$ intervals for each primer, from the average temperature obtained from the equation: $\mathrm{T}_{\mathrm{m}}=(\mathrm{G}+\mathrm{C}) 4+(\mathrm{A}+\mathrm{T}) 2$, and $72^{\circ} \mathrm{C}$ for $3 \mathrm{~min}$ ). After the 42 cycles, a final extension was performed for $7 \mathrm{~min}$ at $72^{\circ} \mathrm{C}$. The amplification products were separated on an agarose gel (2\%), stained with a mixture of Blue Juice 6X with Gel Red, in a proportion of $1: 1$, and the image was revealed by the MiniBis Pro system (Table 1).

Next, the touchdown method was tested for all primers with different programming combinations:

A. Four minutes of denaturation at $94^{\circ} \mathrm{C}$, followed by 30 amplification cycles $\left(94^{\circ} \mathrm{C}\right.$ for $1 \mathrm{~min}, 1 \mathrm{~min}$ with specific $\mathrm{T}_{\mathrm{a}}$ for each primer varying $\pm 7^{\circ} \mathrm{C}$, and $72^{\circ} \mathrm{C}$ for $3 \mathrm{~min}$ ) and 12 cycles $\left(94^{\circ} \mathrm{C}\right.$ for $1 \mathrm{~min}$, decrease of $0.5^{\circ} \mathrm{C}$ from the $\mathrm{T}_{\mathrm{a}}$ of each primer per cycle, and $72^{\circ} \mathrm{C}$ for 3 min). After the 42 cycles, a final extension was performed for $7 \mathrm{~min}$ at $72^{\circ} \mathrm{C}$.

B. Four minutes of denaturation at $94^{\circ} \mathrm{C}$, followed by 32 amplification cycles $\left(94^{\circ} \mathrm{C}\right.$ for $1 \mathrm{~min}, 1 \mathrm{~min}$ with specific $\mathrm{T}_{\mathrm{a}}$ for each primer varying $\pm 7^{\circ} \mathrm{C}$, and $72^{\circ} \mathrm{C}$ per $3 \mathrm{~min}$ ) and 10 cycles $\left(94^{\circ} \mathrm{C}\right.$ for $1 \mathrm{~min}$, decrease of $0.5^{\circ} \mathrm{C}$ from the $\mathrm{T}_{\mathrm{a}}$ of each primer per cycle, and $72^{\circ} \mathrm{C}$ for 3 min). After the 42 cycles, a final extension was performed for $7 \mathrm{~min}$ at $72^{\circ} \mathrm{C}$.

C. Four minutes of denaturation at $94^{\circ} \mathrm{C}$, followed by 30 amplification cycles $\left(94^{\circ} \mathrm{C}\right.$ for $1 \mathrm{~min}, 1 \mathrm{~min}$ with specific $\mathrm{T}_{\mathrm{a}}$ for each primer varying $\pm 7^{\circ} \mathrm{C}$, and $72^{\circ} \mathrm{C}$ for $3 \mathrm{~min}$ ) and 12 cycles $\left(94^{\circ} \mathrm{C}\right.$ for $1 \mathrm{~min}$, decrease of $1.0^{\circ} \mathrm{C}$ from the $\mathrm{T}_{\mathrm{a}}$ of each primer per cycle, and $72^{\circ} \mathrm{C}$ for 3 min). After the 42 cycles, a final extension was performed for $7 \mathrm{~min}$ at $72^{\circ} \mathrm{C}$.

D. Four minutes of denaturation at $94^{\circ} \mathrm{C}$, followed by 32 amplification cycles $\left(94^{\circ} \mathrm{C}\right.$ for $1 \mathrm{~min}, 1 \mathrm{~min}$ with specific $\mathrm{T}_{\text {a }}$ for each primer varying $\pm 7^{\circ} \mathrm{C}$, and $72^{\circ} \mathrm{C}$ for $3 \mathrm{~min}$ ) and 10 cycles $\left(94^{\circ} \mathrm{C}\right.$ for $1 \mathrm{~min}$, decrease of $1.0^{\circ} \mathrm{C}$ from the $\mathrm{T}_{\mathrm{a}}$ of each primer per cycle, and $72^{\circ} \mathrm{C}$ for 3 min). After the 42 cycles, a final extension was performed for $7 \mathrm{~min}$ at $72^{\circ} \mathrm{C}$.

After amplification, the products were separated on an agarose gel (2\%), stained with the mixture Blue Juice $6 \mathrm{X}$ with Gel Red, in a proportion of 1:1, and in a thermocycler for $2 \mathrm{~h}$ at $100 \mathrm{~V}$; the image was revealed by the MiniBis Pro system.

\section{Amplification analyses}

The analyses were made by comparing the gels between the accessions, taking into account gel quality, the band sharpness, the number of bands found, bands lost, bands obtained, number of monomorphic bands, and number of polymorphic bands, when using constant temperature during the 42 cycles and when using the touchdown method. 


\section{RESULTS AND DISCUSSION}

The base temperature taken was that recommended by the manufacturer for a comparative evaluation of the best conditions of annealing temperature. The company RW Genes estimates the annealing temperature based on the equation: $T_{m}=(G+C) 4+(A+T) 2$, but the company Invitrogen considers not only the AT quantity (adenine and thymine) and CG (cytosine and guanine) but also the placement of the oligonucleotides in the primers (equation not available from the company). In 9 of the 15 primers, it was shown that $\mathrm{T}_{\text {a }}$ varied $\pm 3.5^{\circ} \mathrm{C}$ from the $\mathrm{T}_{\mathrm{m}}$ recommended by the company; nevertheless, $\mathrm{T}_{\mathrm{a}}$ of the primers $(\mathrm{CT})_{8} \mathrm{TG},(\mathrm{GA})_{6} \mathrm{CC}$ and (GT) ${ }_{6} \mathrm{CC}$ differed by $10.0^{\circ}, 10.0^{\circ}$ and $8.0^{\circ} \mathrm{C}$, respectively, from the $\mathrm{T}_{\mathrm{m}}$ recommended by the companies. With the primers synthesized by RW Genes, with the degenerate oligonucleotides $(\mathrm{CT})_{8} \mathrm{RC},(\mathrm{GA})_{8} \mathrm{YC}$ and $(\mathrm{CTC})_{5} \mathrm{RC}$, the $\mathrm{T}_{\mathrm{m}}$ was not determined; but it was noticed that after applying the equation $\mathrm{T}_{\mathrm{m}}=(\mathrm{G}+\mathrm{C}) 4+(\mathrm{A}+\mathrm{T}) 2$ there was a variation of $6.5^{\circ}, 1.0^{\circ}$ and $6.0^{\circ} \mathrm{C}$, respectively, from the $\mathrm{T}_{\mathrm{a}}$ with the lower temperature given by the equation, which varies with the oligonucleotides $\left(\mathrm{Y}^{\mathrm{a}}=\mathrm{C}\right.$ or $\mathrm{T} ; \mathrm{R}=\mathrm{A}$ or $\left.\mathrm{G}\right)$ (Table 1$)$. In view of these findings, it is evident that there is a need for performing pre-tests with a temperature gradient for each primer, in order to determine the ideal annealing temperature to provide the highest efficiency of PCR.

\begin{tabular}{|c|c|c|c|c|c|c|c|}
\hline \multirow[t]{2}{*}{ Primer } & \multicolumn{4}{|c|}{ Touchdown } & \multirow[t]{2}{*}{$\mathrm{T}_{\mathrm{m}}\left({ }^{\circ} \mathrm{C}\right)$ company } & \multirow[t]{2}{*}{$\mathrm{T}_{\mathrm{m}}\left({ }^{\circ} \mathrm{C}\right)$ equation } & \multirow[t]{2}{*}{$\mathrm{T}_{\mathrm{a}}\left({ }^{\circ} \mathrm{C}\right)$} \\
\hline & Initial cycles & $\mathrm{T}_{\mathrm{a}}\left({ }^{\circ} \mathrm{C}\right)$ & Final cycles & $\mathrm{T}_{\mathrm{a}}\left({ }^{\circ} \mathrm{C}\right)$ & & & \\
\hline$(\mathrm{CT})_{8} \mathrm{RC}$ & 30 & 47.5 & 12 & $47.5-0.5$ & N/A* & $54 / 56^{* *}$ & 47.5 \\
\hline$(\mathrm{CT})_{8}^{8} \mathrm{TG}$ & 30 & 50 & 12 & 50-0.5 & 54 & 54 & 44 \\
\hline$(\mathrm{GA})_{8} \mathrm{~T}$ & 30 & 53 & 12 & $53-0.5$ & 50 & 50 & 51.5 \\
\hline$(\mathrm{GA})_{8}^{8} \mathrm{YC}$ & 30 & 48 & 12 & $50-0.5$ & N/A* & $54 / 56^{* *}$ & 48 \\
\hline$(\mathrm{CTC})_{5} \mathrm{RC}$ & 30 & 53 & 12 & $53-0.5$ & N/A* & $56 / 58 * *$ & 50 \\
\hline$(\mathrm{GTC})_{6}^{3}$ & 32 & 60 & 10 & $60-0.5$ & 60 & 60 & 58.5 \\
\hline$(\mathrm{GA})_{6} \mathrm{CC}$ & 30 & 42 & 12 & $42-0.5$ & 32 & 44 & 42 \\
\hline$(\mathrm{GT}){ }_{6} \mathrm{CC}$ & 30 & 45 & 12 & $48-1.0$ & 37 & 44 & 45 \\
\hline$(\mathrm{CAC})_{3} \mathrm{GC}$ & 30 & 40 & 12 & $40-0.5$ & 39 & 38 & 37 \\
\hline$(\mathrm{AG})_{8} \mathrm{YT}$ & 30 & 46 & 12 & $46-0.5$ & 42 & $52 / 54 * *$ & 42 \\
\hline$(\mathrm{AC}) \mathrm{CT}$ & 30 & 50 & 12 & $50-0.5$ & 50 & 54 & 47 \\
\hline$(\mathrm{AC})_{8}^{8} \mathrm{YG}$ & 30 & 52 & 12 & $55-0.5$ & 52 & $54 / 56 * *$ & 52 \\
\hline$(\mathrm{CT})_{8}^{8} \mathrm{RG}$ & - & - & - & - & 44 & $54 / 56^{* *}$ & 42 \\
\hline$(\mathrm{GGAT})_{3} \mathrm{GA}$ & 30 & 46 & 12 & $46-0.5$ & 44 & 42 & 40.5 \\
\hline$(\mathrm{GAA})_{6} \mathrm{AA}$ & - & - & - & - & 48 & 52 & 48 \\
\hline
\end{tabular}

*The $\mathrm{T}_{\mathrm{m}}$ equation is non-applicable for the degenerate oligonucleotides. ${ }^{*}$ Values altered according to the nucleotide base: $\mathrm{Y}=\mathrm{C}$ or $\mathrm{T}$, and $\mathrm{R}=\mathrm{A}$ or $\mathrm{G}$. $\mathrm{T}_{\mathrm{a}}=$ annealing temperature; $\mathrm{T}_{\mathrm{m}}=$ melting temperature.

In some research with ISSR markers, it can be seen that annealing temperature is constant for all the primers used (Kantety et al., 1995; Fernandez et al., 2002; Debinath, 2007). However, it is well known that temperature is specific for each design of the ISSR primer used, and that it is directly linked to the presence of CG and with the position of these base pairs (Roux, 1995; Reddy et al., 2002); that is why the efficiency and reliability of producing bands are directly related to the establishment of the ideal annealing temperature.

As an example, we can cite the classic research of Kantety et al. (1995) with common corn and popcorn, in which $45^{\circ} \mathrm{C}$ was established as the annealing temperature for all primers. However, a temperature of $40^{\circ} \mathrm{C}$ could be used for amplification when reevaluating the ideal 
temperature based on the $\mathrm{T}_{\mathrm{m}}$ equation, instead of $45^{\circ} \mathrm{C}$ for the primer $(\mathrm{CA})_{6} \mathrm{R}$. Either way, the estimates of annealing temperatures obtained, which were based on the equation for the primers used by Kantety et al. (1995), did not reveal bands, not even one over $45^{\circ} \mathrm{C}$. Fernandez et al. (2002), in their study of barley, established a $\mathrm{T}_{\mathrm{a}}$ of $52^{\circ} \mathrm{C}$ as standard for all the valid primers, but according to $\mathrm{T}_{\mathrm{m}}$ based on the equation, the annealing temperature of the primers varied from $50^{\circ}$ to $58^{\circ} \mathrm{C}$. On the other hand, it is worthwhile mentioning the study of Carvalho et al. (2002) in corn, in which a specific $\mathrm{T}_{\mathrm{a}}$ was used for each primer. This methodology is indicated in all studies involving ISSR molecular markers because it makes the PCR results reliable, avoiding the emergence of nonspecific bands and the absence of band amplification due to the use of a non-ideal temperature.

Based on the pre-tests performed in the present study, using the annealing temperature gradient for each primer, it could be demonstrated that the higher the temperature the higher the identification of bands with lower molecular weight; on the other hand, the high molecular weight bands were lost because they were not revealed or were shown in smaller amounts in the gels.

With the use of the touchdown method, 10 of the 15 primers evaluated using a gradient varying from $1^{\circ}$ to $10^{\circ} \mathrm{C}$ provided gels with better quality and greater number of bands, namely $(\mathrm{CT})_{8} \mathrm{RC},(\mathrm{CT})_{8} \mathrm{TG},(\mathrm{GA})_{8} \mathrm{~T},(\mathrm{CTC})_{5} \mathrm{RC},(\mathrm{GTC})_{6},(\mathrm{GA})_{6} \mathrm{CC},(\mathrm{CAC})_{3} \mathrm{GC},(\mathrm{AG})_{8} \mathrm{YT}$, $(\mathrm{AC})_{8} \mathrm{CT}$, and (GGAT) ${ }_{3} \mathrm{GA}$. Of these, the majority were efficient with the use of 12 final cycles and a decrease of $0.5^{\circ} \mathrm{C}$, except the primer (GTC) ${ }_{6}$ for which better efficiency occurred with 10 final cycles (Table 1). In relation to the initial temperature, it was noticed that only the primers $(\mathrm{CT})_{8} \mathrm{RC}$ and (GA) ${ }_{6} \mathrm{CC}$ were efficient when the first annealing cycle was performed with the same $T_{a}$. According to Roux (1995), even if the annealing temperature remains below the $T_{m}$ in the final cycles, the amplification reaction in the specified region will have been initiated, preventing nonspecific amplification during the remaining cycles.

The primers $(\mathrm{GA})_{8} \mathrm{YC},(\mathrm{GT})_{6} \mathrm{CC},(\mathrm{AC})_{8} \mathrm{YG},(\mathrm{CT})_{8} \mathrm{RG}$, and (GAA) ${ }_{6} \mathrm{AA}$ were not efficient using the touchdown method; subsequently, $\mathrm{T}_{\mathrm{a}}$ was applied in the initial cycles and a $1^{\circ}$ to $5^{\circ} \mathrm{C}$ gradient was used in the final cycles, with a temperature decrease $\left(0.5^{\circ}\right.$ or $\left.1.0^{\circ} \mathrm{C}\right)$ and adjustment in the final cycles ( 10 or 12 cycles). There was an improvement in the amplified bands for the majority of the primers with this modification in the procedure. The primers $(\mathrm{GT})_{6} \mathrm{CC}$ and $(\mathrm{AC})_{8} \mathrm{YG}$ provided better gel quality when performing these 12 final cycles and with an increase of $3^{\circ} \mathrm{C}$ in the last cycles, whereas for the $(\mathrm{GA})_{8} \mathrm{YC}$ primer, the best results were possible with an increment of $2^{\circ} \mathrm{C}$ in the 12 last cycles. However, based on the revelation of the gels, the primer (GT) ${ }_{6} \mathrm{CC}$ proved to have a better annealing efficiency when using a $1.0^{\circ} \mathrm{C}$ decrease per cycle, whereas for the $(\mathrm{AC})_{8} \mathrm{YG}$ and $(\mathrm{GA})_{8} \mathrm{YC}$ primers, the same happened when a decrease of $0.5^{\circ} \mathrm{C}$ was used (Table 1 and Figure 1).

According to these results, the touchdown-PCR method should not be regarded as a method to be used in a general way for all primers, but it cannot be denied that for the majority of them, the results obtained here revealed that the technique provided better efficiency in band amplification for the crops of common corn, popcorn, sweet corn, and Tripsacum-maize hybrid. This was mainly due to the use of higher annealing temperatures.

Some investigators have used the touchdown technique with ISSR markers (Martins et al., 2003, 2004), but the methodological procedure is not clearly described because it does not contain the necessary information to allow the repetition of the works, not even studies that can validate or not the efficiency of the temperatures and cycles employed. Therefore, the results presented here are of great importance for future research in the cultivation of common 
corn, popcorn, sweet corn, and Tripsacum-maize hybrid, because the experimental process of determining the optimal conditions of temperature for a representative group of primers is of great importance in the economy of resources, time and effort.

(GT)6CC
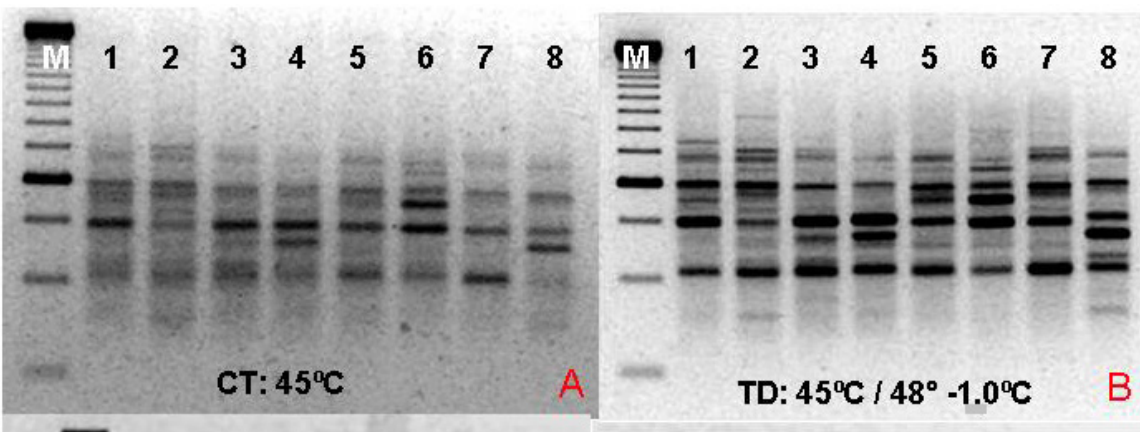

(CT)8TG

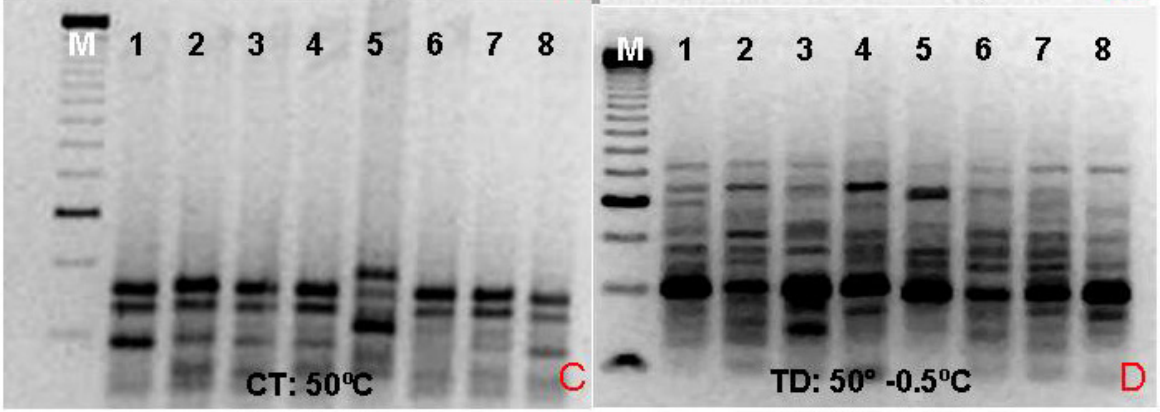

Figure 1. A. and B. PCR product when amplified with the $(\mathrm{GT})_{6} \mathrm{CC}$ primer at constant temperature and when using the touchdown method, respectively. C. and D. PCR product using the (CT) ${ }_{8}$ TG. In $C$ the temperature was higher than $\mathrm{T}_{\mathrm{a}}\left(44^{\circ} \mathrm{C}\right)$, in which there was a loss of bands of higher molecular weight and gain of bands of lower molecular weight. $D$ refers to gel revealed after the use of the touchdown method and the use of high temperature $\left(50^{\circ} \mathrm{C}\right)$ in the 30 initial cycles and decrease of $0.5^{\circ} \mathrm{C}$ per cycle in the last 12 cycles, in which a larger number of bands of higher molecular weight can be visualized, without the loss of bands of lower molecular weight. $\mathrm{M}=25$ bp High DNA Mass Ladder (Invitrogen, USA). Lane 1 = "Centralmex" (common corn of the dent type); lane $2=$ "Tripsacum-maize hybrid"; lane 3 = "Doce de Cuba" (sweet corn); lane 4 = "Cimmyt" (common corn of the flint type); lane 5 = "Cateto Amarelo" (common corn of the dent type); lane 6= "IAC-112" (popcorn); lane 7 = "BOZM 260 " (popcorn), and lane $8=$ "PR 023" (popcorn). CT = constant annealing temperature; TD = touchdown method.

\section{REFERENCES}

Bernardo R (2008). Molecular markers and selection for complex traits in plants: learning from the last 20 years. Crop Sci. 48: 1649-1664.

Caixeta ET, Oliveira ACB, Brito GG and Sakiyama NS (2006). Tipos de Marcadores Moleculares. In: Marcadores Moleculares (Borém A and Caixeta ET, eds.). Universidade Federal de Viçosa, Viçosa, 9-78.

Carvalho VP, Ruas PM, Ruas CF, Ferreira JM, et al. (2002). Assessment of genetic diversity in maize (Zea mays L.) landraces using inter simple sequence repeat (ISSR) markers. Crop Breed. Appl. Biotechnol. 2: 557-568.

Daher RF, Pereira MG, Tupinamba EA, Amaral Júnior AT, et al. (2002). Assessment of coconut tree genetic divergence by compound sample RAPD marker analysis. Crop Breed. Appl. Biotechnol. 3: 431-438.

Debnath SC (2007). Inter-simple sequence repeat (ISSR)-PCR analysis to assess genetic diversity in a collection of wild cloudberry (Rubus chamaemorus L.) clones. J. Hort. Sci. Biotechnol. 82: 727-732.

Don RH, Cox PT, Wainwright BJ, Baker K, et al. (1991). 'Touchdown' PCR to circumvent spurious priming during gene amplification. Nucleic Acids Res. 19: 4008. 
Doyle JJ and Doyle JL (1990). Isolation of plant DNA from fresh tissue. Focus 12: 13-15.

Eathington SR, Crosbie TM, Edwards MD, Reiter RS, et al. (2007). Molecular markers in a commercial breeding program. Crop Sci. 47: S154-S163.

Fernandez ME, Figueiras AM and Benito C (2002). The use of ISSR and RAPD markers for detecting DNA polymorphism, genotype identification and genetic diversity among barley cultivars with known origin. Theor. Appl. Genet. 104: 845-851.

Gonçalves LS, Rodrigues R, do Amaral Junior AT, Karasawa M, et al. (2009). Heirloom tomato gene bank: assessing genetic divergence based on morphological, agronomic and molecular data using a Ward-modified location model. Genet. Mol. Res. 8: 364-374.

Hyndman DL and Mitsuhashi M (2003). PCR primer design. Methods Mol. Biol. 226: 81-88.

Kantety RV, Zeng X, Bennetzen J and Zehr BE (1995). Assessment of genetic diversity in dent and popcorn (Zea mays L.) inbred lines using inter-simple sequence repeat (ISSR) amplification. Mol. Breed. 1: 365-373.

Kubista M, Andrade JM, Bengtsson M, Forootan A, et al. (2006). The real-time polymerase chain reaction. Mol. Aspects Med. 27: 95-125.

Market C and Moller F (1959). Multiple forms of enzymes: Tissue, autogene and species patterns. Proc. Nat. Acad. Sci. 45: 753-763.

Martins M, Tenreiro R and Oliveira MM (2003). Genetic relatedness of Portuguese almond cultivars assessed by RAPD and ISSR markers. Plant Cell Rep. 22: 71-78.

Martins M, Sarmento D and Oliveira MM (2004). Genetic stability of micropropagated almond plantlets, as assessed by RAPD and ISSR markers. Plant Cell Rep. 23: 492-496.

Mullis KB and Faloona FA (1987). Specific synthesis of DNA in vitro via a polymerase-catalyzed chain reaction. Methods Enzymol. 155: 335-350.

Reddy MP, Sarla N and Siddiq EA (2002). Inter simple sequence repeat (ISSR) polymorphism and its application in plant breeding. Euphytica 128: 9-17.

Roux KH (1995). Optimization and troubleshooting in PCR. PCR Methods Appl. 4: S185-S194.

Schlötterer C (2004). The evolution of molecular markers - just a matter of fashion? Nat. Rev. Genet. 5: 63-69.

Schulman AH (2007). Molecular markers to assess genetic diversity. Euphytica 158: 313-321.

Zietkiewicz E, Rafalski A and Labuda D (1994). Genome fingerprinting by simple sequence repeat (SSR)-anchored polymerase chain reaction amplification. Genomics 20: 176-183. 